\title{
The Relationship between Working Capital Management and Profitability
}

\author{
Nasser A. Alsulayhim ${ }^{1}$ \\ ${ }^{1}$ Accounting department, Institute of Public Administration, Riyadh, Saudi Arabi \\ Correspondence: Nasser Alsulayhim, Accounting department, Institute of Public Administration, Riyadh, Saudi \\ Arabi.
}

Received: June 24, 2019

doi:10.5539/ibr.v12n8p142

\author{
Accepted: July 9, 2019 Online Published: July 29, 2019 \\ URL: https://doi.org/10.5539/ibr.v12n8p142
}

\begin{abstract}
Working capital management is an important concept that could influence companies in many ways. An efficient management of working capital can help a company to manage its finances and increases its profitability. This study investigates the relationship between working capital management and profitability in non-financial companies listed in the Saudi Stock Exchange. A sample of 67 companies is used for a period of ten years (2007-2016). Quantitative method using multiple linear regression and pooled data set is used for analysis. The results indicate a positive relationship between working capital management and profitability. However, each company could have a different optimal level of working capital and could require different strategies to increase profitability. This study is limited to non-financial companies listed in the Saudi Stock Exchange. This study is a positive contribution to working capital management literature as it uses a relatively large sample, a longer time period, and multiple profitability proxies in the context of Saudi Arabia which has few researches in this area.
\end{abstract}

Keywords: working capital management, WCM, non-financial companies, profitability, stock exchange, Saudi Arabia

\section{Introduction}

A company needs to ensure that there is sufficient cash to cover its operational expenses on a daily basis. A shortage of cash could affect a company ability to pay its bills, and it can go out of business. Companies can acquire cash either internally or externally and each choice has a different cost, depending on the situation of the company. Managing the right amount of cash, from the right source, and at the lowest cost, is called working capital management (WCM). WCM is very important for the survival of a company because of its implications on a company's profitability, risk, and value (Smith, 1980).

Working capital and its management is a matter of concern for most companies. Usually, companies have a large portion of cash invested in working capital, using some of it as a source of financing, which makes WCM a very important part of the company's financial management. Moreover, the way any company handles its working capital can influence its profitability and can maximise the value of the company (Deloof, 2003). Working capital has a significant role in maximising the shareholders' value (Ukaegbu, 2014), which is the ultimate goal for each company.

The way a company manages its working capital could be conservative, aggressive, or moderate. Each of these approaches has costs and benefits. It is important for working capital policy makers to consider company's type and its business, as not all companies have the same requirements of working capital. Competition is an important factor in determining the company policy of working capital management (Singhania, Sharma \& Rohit, 2014).

Working capital is the subtraction of current liability from current assets (working capital = current assets current liability) (Singhania, Sharma et al. 2014). Working capital includes current assets, such as accounts receivable, which accrue by credit sales to customers. Giving customers a short period to pay the due amount could lead to the loss of customers who can find a longer credit period with another competitor. However, giving those customers a longer credit period to pay the due amount could create a cash shortage for the company. Another working capital component is accounts payable, created by credit merchandise from suppliers. This can be a source of low-cost and flexible financing for the company; however, late payment of invoices could cost the 
company the benefit of any discounts for early payments (Deloof, 2003). Moreover, a company's liquidity problems can affect its level of goodwill and its credit rating (Singhania et al., 2014).

Some studies have indicated that working capital appears to be more important during recessions as compare to boom (Enqvist, Graham \& Nikkinen, 2014). They argued, in the presence of rapid economic fluctuations, the importance of WCM increases. Furthermore, a company with good management of working capital would be able to react quickly during recession (Ukaegbu, 2014), which can help it to avoid a financial crisis.

From the above introduction one can see the importance of WCM; however, there appears to be a lack of research regarding the relationship between WCM and profitability of companies in developing countries. Although a number of studies have been conducted on the relationship between WCM and profitability, most of them have focused on the United States (US) market. Furthermore, according to Madhou, Moosa and Ramiah (2015), the focus of previous empirical studies was limited to either specific industries (such as retail, manufacturing, and banking) or they are out-dated. The current paper aims to provide empirical evidence on the relationship between WCM and profitability of companies in Saudi Arabia, a major developing country. This study was conducted on non-financial companies listed on the Saudi Arabia Stock Exchange for a period of ten years (2007-2016), covering different economic conditions, including the 2008 world financial crisis.

\subsection{Literature Review}

\section{Previous results}

Many studies examined the relationship between working capital management, its components, and the companies profitability. The results revealed by those studies were mixed. Danuletiu (2010) investigated the relationship between profitability and WCM in a sample of twenty companies. The analysis presented a negative but weak correlation between profitability and WCM. The author explained this weak relationship by highlighting the fact that the companies used for the study were from different industrial sectors. Almazari (2013) examined the relationship between WCM and companies profitability in a sample of eight Saudi-listed companies of the cement industry. His sample covered the period between 2008-2012. He used cash conversion cycle (CCC) and its components as a method for measuring WCM. Gross operating profit (GOP) was used as in Almazari's study as a proxy of profitability. Using regression and correlation analysis, the author found that working capital management was positively associated with profitability. Other studies such as Rahman (2011), Usama (2012), and Ali and Ali (2012) also reported a positive relationship between profitability and WCM.

On the other hand, A study conducted by Eljelly (2004) discussed the relationship between liquidity measured by CCC and current ratio (CR) and profitability; and found a negative relationship. Eljelly included a sample of 29 Saudi-listed companies from three diffrent sectors including industry, agriculture, and services. The study covered the period of 1996-2000. The author observed that the profitability was negatively related to liquidity. Moreover, CR was observed to be the most significant measure that influenced profitability. Mohamad and Saad (2010) selected a random sample of 172 companies listed on Bursa Malaysia during 2003-2007 and analyse the impact of WCM on the profitability. The results of this study showed a negative relationship of three components of WCM on profitability. Ghaziani, Biabani and Zadeh (2012) found a significant and negative association between profitability and WCM. Arshad and Gondal (2013) conducted a study involving 21 companies listed on the stock exchange of Karachi during the years 2004-2010 and found that WCM had a significantly negative relationship with companies profitability.

Differently, a U-shape correlation were revealed by other studies. Baños-Caballero, García-Teruel Martinez-Solano (2014) noted the existence of a U-shape relationship between companies profitability and working capital. Mun and Jang (2015) also reported the same type of U-shape relationship between profitability and WCM in a sample of US restaurants.

\section{Measurements of WCM}

Previous studies have used various measurements of WCM (Ahmed et al., 2016). The Most common measurements were CCC and its components (inventories, receivable, and payable), CR, and net trade cycle (NTC). Many studies including Raheman and Nasr (2007), Eljelly (2004), Singh and Pandey (2008), and Arshad and Gondal (2013) used CR as a measurement for WCM. But, the use of CR as a way of measuring WCM has often been criticized due to the reason that it calculates the company's liquidity at a particular time (Ukaegbu, 2014; Uyar, 2009).

CCC is the most used way to measure WCM. CCC shows the time lag between buying raw materials, converting them into finished goods, and cash collection from the process of sales (Deloof, 2003). Studies such as Singhania et al. (2014), Eljelly (2004), Deloof (2003), and Wang (2002), applied this measurement, either separately or 
along with some other measurements.

NTC also has been used as WCM mesurent in a number of studies. It is related to the trade (sales) cycle instead of the operation cycle. NTC, in other words, can be considered equivalent to CCC, but in form of sales percentage. Many studies, such as Baños-Caballero et al. (2014), Shin and Soenen (1998), Soenen (1993), applied NTC for measuring WCM. However, Raheman et al. (2010) NTC and CCC measure the liquidity in a different way compared to $\mathrm{CR}$.

\section{Profitability proxies}

Previous studies have used various profitability ratios as profitability proxies in examining the relationship between profitability and WCM. The most commonly used proxies are return on equity (ROE), return on assets (ROA), gross operating profit (GOP), return on capital employed (ROCE), and net operating profit (NOP). Some of the studies applied one profitability proxy, while others used more than one.

Studies such as Ahmed et al. (2016) and Enqvist et al. (2014) have used ROA as a profitability proxy. Although ROA may not be impacted by capital structure, it may be influenced by unnatural assets' growth (Barber and Lyon, 1996). ROE has been used by many researchers including Samiloglu and Akgun (2016), and Jose, Lancaster, Stevens (1996) and. ROE is less preferable profitability proxy due to the fact that it is influenced by the capital structure and it excludes all other amounts which are invested by debtors.

ROCE is another profitability proxy. It was used by Muhammad, Rehman, Waqas (2016) and Mohamad and Saad (2010). ROCE is a ratio of the return on employed capital (liabilities and equity). Using ROCE was limited in previous studies comparing to GOP, ROA, and NOP (Singh, Kumar \& Colombage, 2017).

GOP is the most commonly used in previous studies (Almazari, 2013; Deloof, 2003; Singhania et al., 2014). This is because GOP does not involve assets which are calculated by the historical costs like ROA. Moreover, GOP, unlike ROE is not influenced by capital structure. Furthermore, operating income used to measure GOP is often excluded from any type of obscurity which might be caused due to interest or tax (Barber and Lyon, 1996).

Finally, a number of previous studies have used NOP as a profitability proxy (Haron and Nomran, 2016; Raheman et al., 2010). NOP is measured in a similar to GOP, but NOP includes overhead expenses.

\section{Economic conditions}

Economic conditions can influence financing decisions consequently affect WCM (Korajczyk \& Levy, 2003). Although a number of studies have examined the effect of different economic conditions on the relationship between WCM and profitability, no constant results were obtained. Further studies could help to provide a clearer understanding Ukaegbu (2014). Enqvist et al. (2014) observed more obvious effect of WCM on profitability during poor economic conditions as compared to the good economic conditions. Haron and Nomran (2016) analyzed 57 Malaysian companies before, during, and after the 2008 global financial crisis. They observed that the relationship between WCM and profitability remains the same despite of the differences in economic condition.

\subsection{Research Objective and Questions}

The objective of this study is to determine if working capital management affect profitability of companies in Saudi Arabia through answering the following questions:

- Is there a relationship between WCM and the profitability of non-financial companies listed on the Stock Exchange of Saudi Arabia?

- If there is a relationship between WCM and the profitability of non-financial companies listed on the Saudi Arabia Stock Exchange, do economic conditions affect this relationship?

- If there is a relationship between profitability and WCM of non-financial companies listed on the Saudi Arabia Stock Exchange, does the company size affect this relationship?

\subsection{Research Hypothesis}

Previous studies have established different relationships between WCM and profitability in specific sectors. However, this study is considering all non-financial companies listed on the Stock Exchange of Saudi Arabia covering all non-financial sectors; which provide a comprehensive view.

H0: There is no relationship between WCM and profitability in non-financial companies listed in the Saudi Arabia Stock Exchange.

H1: There is a significant relationship between WCM and profitability in non-financial companies listed in the Saudi Arabia Stock Exchange if there is any significant relationship between current ratio (CR), receivable 
collection period (RCP), accounts payable period (APP), or inventory period (INP) and Return on Assets (ROA), Return on Equity (ROE), Return on Capital Employed (ROCE), Gross Operating Profit (GOP), or Net Operating Profit (NOP).

In general, a short time in RCP means less investment in working capital, which suggests that company managers can create value for the company by reducing the number of days in accounts receivable (Deloof, 2003). Therefore, we expected to find a significantly inverse relationship between RCP and profitability. This produced the second hypothesis:

$\mathrm{H} 2$ : There is a significant negative relationship between RCP and profitability in non-financial companies listed on the Stock Exchange of Saudi Arabia.

A high level of inventory is assumed to enhance sales and reduce the transaction costs (Petersen \& Rajan, 1997; Lyngstadaas \& Berg, 2016). Therefore, we predicted a positive relationship between INP and profitability, which led to the third hypothesis:

H3: There is a significant positive relationship between INP and profitability in non-financial companies listed on the Saudi Arabia Stock Exchange.

Suppliers may grant discounts to companies if they pay earlier, which reduces the cost of goods and increases profitability (Deloof, 2003; Lyngstadaas \& Berg, 2016). Therefore, we expected an inverse or negative relationship between APP and profitability, which led to the fourth hypothesis:

H4: There is a significant negative relationship between APP and profitability in non-financial companies listed on the Saudi Arabia Stock Exchange.

Low level of liquidity could lead to a financial crisis (Ukaegbu, 2014). Companies with an appropriate liquidity position can cover their day-to-day operations and short-term debt (Ahmed et al., 2016), which may increase profitability. Moreover, liquidity and profitability have been linked closely in previous studies (Samiloglu ad Akgun, 2016). Therefore, we expected to find a positive relationship between CR and profitability, which led to the fifth hypothesis:

H5: There is a significant positive relationship between CR and profitability in non-financial companies listed on the Saudi Arabia Stock Exchange.

Company size was included as a control variable in this study. Previous studies have shown different relationships between company size and profitability. We aimed to reveal any possible interaction between company size, WCM, and profitability. Therefore, the sixth hypothesis was:

H6: There is a strong relationship between size of the company and profitability in non-financial companies listed on the Saudi Arabia Stock Exchange.

Previous studies have shown that economic conditions can have an effect on the relationship between WCM and profitability, particularly in low economic conditions (Enqvist et al. 2014). Therefore, we expected that gross domestic product (GDP), as a measurement of economic conditions, would interact with the relationship between WCM and profitability, which led to the seventh hypothesis:

H7: GDP annual growth significantly affects the relationship between WCM and profitability in non-financial companies listed on the Saudi Arabia Stock Exchange.

\section{Methodology}

\subsection{Research Design}

This research used a quantitative approach and deductive reasoning, which begins by stating a set of hypotheses and then collecting data from a sample that represents the population to test those hypotheses. This approach is suitable for studies seeks to generalize its results on the study population.

\subsection{Scope of the Research}

The scope of this research was limited to non-financial companies listed in the main Saudi Arabia Stock Exchange, as on 31 December 2016. The research focus was the ten year period from 2007- 2016. Tadawul, the official website for the Saudi Arabia Stock Exchange, revealed that for this period, the Saudi Stock Exchange listed 175 companies from 20 different sectors. These sectors included materials, services, energy, capital goods, food and staples, transportation, consumer apparel, consumer durables, consumer services, retailing, media, healthcare, beverages, pharma, insurance, real estate, banks, diversified financial, telecommunication, REITs, and utilities. 


\subsection{Sample Selection}

As this study involved only non-financial companies, companies from the following sectors were excluded: banks, diversified financial, and insurance because they have different characteristics and accounting regulations from non-financial companies (Nurunnabi, 2017). Companies that did not have constant data over the ten years period (2007-2016) were excluded to ensure a valid result (Mun \& Jang, 2015; Lyngstadaas \& Berg, 2016; Singh et al., 2017).

The final sample consisted of 670 company-year observation points, comprising data from 67 companies over the ten year period. The period of ten years was chosen to obtain a suitable number of observations covering a range of economic conditions and changes. The final sample covered all non-financial sectors and it included approximately $52 \%$ of the total number of non-financial listed companies, which was considered an appropriate representative sample of the population.

\subsection{Data Collection}

To examine the relationship between WCM and profitability in non-financial companies listed in Saudi Arabia Stock Exchange, secondary data was used that was obtained from Orbis database. This database is well known for its reliability and has a universal acceptance (Ukaegbu, 2014). A number of filters were applied to find the data of non-financial companies listed in Saudi Arabia Stock Exchange and to exclude companies with missing data during the study period.

\subsection{Variable Selection}

This study has used five profitability proxies as dependent variables: ROA, ROE, ROCE, GOP, and NOP. For independent variables, measurements of WCM, CCC components and CR were used. The CCC components were accounts receivable collection period (RCP), accounts payable period (APP), and inventory period (INP). Although CCC has been used extensively in previous studies, only components of CCC were included in this study's regression models because of the high collinearity between CCC and its components. CR has been identified as the most important liquidity measurement in previous studies in Saudi Arabia (Eljelly, 2004; Almazari, 2013). It has been used as a measurement of WCM because of the direct effect of WCM practices on companies' liquidity (Enqvist et al., 2014).

Size of company (measured by sales) was included as a control variable in this study to test whether this factor affected the correlation between WCM and profitability. Previous studies have found different results regarding the effect of company size on profitability (Lyngstadaas \& Berg, 2016). A number of studies have included company size as a control variable to enable an opposite analysis of WCM and company profitability (Deloof, 2003; Ukaegbu, 2014).

GDP annual growth was used in this current study as an independent variable to test whether the economic conditions affected the interrelationship between profitability and WCM. Generally, GDP is an indicator to check regular fluctuations in economic activity (Enqvist et al., 2014), and economic conditions may have an effect on the investment level, profitability and working capital (Lyngstadaas and Berg, 2016). However, in current study, GDP annual growth was not included in the estimated models for the multiple linear regression analyses, but was used as a repeated measures analysis through ten observation points during the study period.

\subsection{Data Analysis}

Five multiple regressions were run using SPSS (Allen \& Bennett, 2012). Each independent variable included in the models (CR, RCP, INP, APP, and Size) was regressed against each dependent variable (ROA, ROE, ROCE, GOP, and NOP).

After the final models had been obtained, repeated measures using Saudi Arabia GDP annual growth for each of the ten years of the study period were applied to identify any significant effect of GDP on the slope of the obtained model. These tests were sufficient and appropriate for this study, and they were comparable with a number of previous studies (Eljelly, 2004; Almazari 2013; Pais \& Gama, 2015; Samiloglu \& Akgün, 2016).

\section{Results}

Regression analyses were used to test how much of the variability of the dependant variable could be explained by the independent variables, using the following model:

$$
\mathrm{ROA}_{\mathrm{it}}=\beta 0+\beta 1 \mathrm{CR}_{\mathrm{it}}+\beta 2 \mathrm{RCP}_{\mathrm{it}}+\beta 3 \mathrm{APP}_{\mathrm{it}}+\beta 4 \mathrm{INP}_{\mathrm{it}}+\beta 5 \mathrm{Size}_{\mathrm{it}}+\varepsilon
$$


Table 1. Relationship between ROA and other variables

\begin{tabular}{|c|c|c|c|c|c|c|c|}
\hline \multicolumn{8}{|c|}{ Standardized } \\
\hline & Standardized & Coefficients & Coefficient & & & Collinearity & statistics \\
\hline odel & B & Std. error & Beta & $\mathrm{t}$ & Sig. & Tolerance & VIF \\
\hline (Constant) & 8.608 & .843 & & 10.201 & .000 & & \\
\hline CR & .856 & .193 & .171 & 4.441 & .000 & .909 & 1.100 \\
\hline $\mathrm{RCP}$ & -.017 & .005 & -.128 & -3.430 & .001 & .979 & 1.022 \\
\hline INP & .010 & .020 & .018 & .485 & .628 & .971 & 1.030 \\
\hline APP & -.046 & .008 & -.209 & -5.545 & .000 & .953 & 1.049 \\
\hline Size & .004 & .003 & .047 & 1.265 & .206 & .964 & 1.037 \\
\hline
\end{tabular}

Note. $\mathrm{ROA}=$ Dependent variable

From the coefficients results (Table 1), the final model could be expressed as:

$$
\text { ROA it }=.856(\mathrm{CRit})-.017(\mathrm{RCPit})-.046(\mathrm{APPit})+.01(\mathrm{INPit})+.004(\text { Size it })+8.608
$$

The model overall was statistically significant at $\mathrm{p}<.001$; however, the significance of each variable was different. CR and APP were statistically significant, at $\mathrm{p}<.001$, RCP was statistically significant at $\mathrm{p}=.001$, but INP and Size were not statistically significant. The collinearity results showed that every independent variable in the tested model was unique and predicted different parts of the dependent variable, which in this case was ROA.

Following model was used to test how much variability of ROE could be explained by independent variables:

$$
\mathrm{ROE} \text { it }=\beta 0+\beta 1 \mathrm{CR} \text { it }+\beta 2 \mathrm{RCP} \text { it }+\beta 3 \mathrm{APP} \text { it }+\beta 4 \text { INP it }+\beta 5 \text { Size it }+\varepsilon
$$

\begin{tabular}{|c|c|c|c|c|c|c|c|}
\hline \multirow[b]{3}{*}{ Model } & \multicolumn{6}{|c|}{ Standardized } & \multirow{3}{*}{$\begin{array}{c}\text { statistics } \\
\text { VIF }\end{array}$} \\
\hline & Standardized & coefficients & Coefficient & & & Collinearity & \\
\hline & $\mathrm{B}$ & Std. error & Beta & $\mathrm{t}$ & Sig. & Tolerance & \\
\hline (Constant) & 15.059 & 1.268 & & 11.878 & .000 & & \\
\hline $\mathrm{CR}$ & .273 & .290 & .037 & .944 & .346 & .909 & 1.100 \\
\hline $\mathrm{RCP}$ & -.026 & .008 & -.129 & -3.401 & .001 & .979 & 1.022 \\
\hline INP & .020 & .030 & .026 & .673 & .501 & .971 & 1.030 \\
\hline APP & -.060 & .012 & -.186 & -4.845 & .000 & .953 & 1.049 \\
\hline Size & .015 & .005 & .112 & 2.935 & .003 & .964 & 1.037 \\
\hline
\end{tabular}

Table 2. Relationship between ROE and other variables

Note. $\mathrm{ROE}=$ Dependent variable

From the coefficients result (Table 2), the final model could be expressed as:

$$
\text { ROE it }=.273(\text { CRit })-.026(\text { RCPit })-.06(\text { APPit })+.02(\text { INPit })+.015(\text { Size it })+15.06
$$

The model overall was statistically significant at $\mathrm{p}<.001$; however, the significance of each variable was different. RCP and APP were statistically significant at $\mathrm{p} \leq .001$, Size was statistically significant at $\mathrm{p}<.05$, but $\mathrm{CR}$ and INP were not statistically significant. The collinearity results showed that every independent variable in the tested model was unique and predicted different parts of the dependent variable, which in this case was ROE.

Following model was used to test how much variability of ROCE could be explained by independent variables:

$$
\mathrm{ROCE}_{\mathrm{it}}=\beta 0+\beta 1 \mathrm{CR}_{\mathrm{it}}+\beta 2 \mathrm{RCP}_{\mathrm{it}}+\beta 3 \mathrm{APP}_{\mathrm{it}}+\beta 4 \mathrm{INP}_{\mathrm{it}}+\beta 5 \mathrm{Size}_{\mathrm{it}}+\varepsilon
$$


Table 3. Relationship between ROCE and other variables

\begin{tabular}{|c|c|c|c|c|c|c|c|}
\hline \multirow[b]{3}{*}{ Model } & \multirow{3}{*}{$\begin{array}{c}\text { Standardized } \\
\text { B }\end{array}$} & \multirow{3}{*}{$\begin{array}{r}\text { coefficients } \\
\text { Std. error } \\
\end{array}$} & \multicolumn{5}{|l|}{ Standardized } \\
\hline & & & Coefficient & & & Collinearity & statistics \\
\hline & & & Beta & $\mathrm{t}$ & Sig. & Tolerance & VIF \\
\hline (Constant) & 11.494 & 1.392 & & 8.258 & .000 & & \\
\hline $\mathrm{CR}$ & .622 & .352 & .083 & 1.767 & .078 & .878 & 1.139 \\
\hline $\mathrm{RCP}$ & -.015 & .008 & -.081 & -1.775 & .077 & .952 & 1.051 \\
\hline INP & .060 & .030 & .091 & 2.011 & .045 & .967 & 1.034 \\
\hline APP & -.018 & .018 & -.047 & -1.005 & .315 & .889 & 1.124 \\
\hline Size & .005 & .005 & .045 & .994 & .321 & .940 & 1.064 \\
\hline
\end{tabular}

Note. ROCE $=$ Dependent variable

From the coefficients result (Table 3), the final model could be expressed as:

$$
\text { ROCE it }=.622 \text { (CRit) }-.015 \text { (RCPit) }-.018(\text { APPit })+.06(\text { INPit })+.005 \text { (Size it })+11.494
$$

The model overall was statistically significant at $\mathrm{p}<.05$; however, the significance of each variable was different. Only INP was statistically significant at $\mathrm{p}<.05$; however, the rest of the variables were not statistically significant.

Following model was used to test how much variability of GOP could be explained by independent variables:

$$
\mathrm{GOP}_{i t}=\beta 0+\beta 1 \mathrm{CR}_{\mathrm{it}}+\beta 2 \mathrm{RCP}_{\mathrm{it}}+\beta 3 \mathrm{APP}_{\mathrm{it}}+\beta 4 \mathrm{INP}_{\mathrm{it}}+\beta 5 \mathrm{Size}_{\mathrm{it}}+\varepsilon
$$

\begin{tabular}{|c|c|c|c|c|c|c|c|}
\hline \multirow[b]{3}{*}{ Model } & \multirow{3}{*}{$\begin{array}{l}\text { Standardized } \\
\text { B }\end{array}$} & \multirow{3}{*}{$\begin{array}{l}\text { coefficients } \\
\text { Std. error }\end{array}$} & \multicolumn{5}{|l|}{ Standardized } \\
\hline & & & Coefficient & & & Collinearity & statistics \\
\hline & & & Beta & $\mathrm{t}$ & Sig. & Tolerance & VIF \\
\hline (Constant) & 34.701 & 1.717 & & 20.207 & .000 & & \\
\hline $\mathrm{CR}$ & 2.334 & .392 & .229 & 5.949 & .000 & .909 & 1.100 \\
\hline $\mathrm{RCP}$ & .016 & .010 & .056 & 1.514 & .130 & .979 & 1.022 \\
\hline INP & .104 & .040 & .096 & 2.594 & .010 & .971 & 1.030 \\
\hline APP & -.078 & .017 & -.174 & -4.630 & .000 & .953 & 1.049 \\
\hline Size & -.005 & .007 & -.029 & -.775 & .439 & .964 & 1.037 \\
\hline
\end{tabular}

Table 4. Relationship between GOP and other variables

Note. GOP = Dependent variable

From the coefficients results (Table 4 ), the final model could be expressed as:

$$
\text { GOP it }=2.33(\text { CRit })+.016(\text { RCPit })-.078(\text { APPit })+.104(\text { INPit })-.005(\text { Size it })+34.701
$$

The model overall was statistically significant (at $\mathrm{p}<.001$ ); however, the significance of each variable was different. CR and APP were statistically significant, at $\mathrm{p}<.001$ ), INP was statistically significant, at $\mathrm{p}<.05$ ), but RCP and Size were not statistically significant. The collinearity results showed that every independent variable in the tested model was unique and predicted different parts of the dependent variable, which in this case was GOP.

Following model was used to test how much variability of NOP could be explained or predicted by independent variables:

$$
\mathrm{NOP}_{i t}=\beta 0+\beta 1 \mathrm{CR}_{\mathrm{it}}+\beta 2 \mathrm{RCP}_{\mathrm{it}}+\beta 3 \mathrm{APP}_{\mathrm{it}}+\beta 4 \mathrm{INP}_{\mathrm{it}}+\beta 5 \mathrm{Size}_{\mathrm{it}}+\varepsilon
$$


Table 5. Relationship between NOP and other variables

\begin{tabular}{|c|c|c|c|c|c|c|c|}
\hline & Standardized & coefficients & $\begin{array}{l}\text { Standardized } \\
\text { Coefficient }\end{array}$ & & & Collinearity & statistics \\
\hline Model & B & Std. error & Beta & $\mathrm{t}$ & Sig. & Tolerance & VIF \\
\hline (Constant) & 16.593 & 1.779 & & 9.326 & .000 & & \\
\hline CR & 2.652 & .405 & .247 & 6.551 & .000 & .911 & 1.098 \\
\hline RCP & -.017 & .011 & -.060 & -1.635 & .103 & .977 & 1.023 \\
\hline INP & .107 & .041 & .094 & 2.581 & .010 & .971 & 1.029 \\
\hline APP & -.114 & .018 & -.228 & -6.176 & .000 & .953 & 1.049 \\
\hline Size & .005 & .007 & .024 & .658 & .511 & .963 & 1.038 \\
\hline
\end{tabular}

From the coefficients results (Table 5), the final model could be expressed as:

$$
\text { NOP it }=2.65(\text { CRit })-.017(\text { RCPit })-.114(\text { APPit })+.15(\text { INPit })+.005(\text { Size it })+16.6
$$

The model overall was statistically significant at $\mathrm{p}<.001$; however, the significance of each variable was different. CR and APP were statistically significant, at $\mathrm{p}<.001$, INP was statistically significant, at $\mathrm{p}<.05$, but RCP and Size were not statistically significant. The collinearity results showed that every independent variable in the tested model was unique and predicted different part of the dependent variable, which in this case was NOP.

Saudi economy passed through different economic conditions during 2007-2016, with fluctuating figures for GDP growth. Figures obtained from the World Bank website showed ten different GDP growth percentages for these years, which were applied in this study. The NOP model was applied to identify any significant effect of GDP on the regression slope, because NOP was the profitability proxy that was most explained by the independent variables of this study.

Table 6. Type III tests of fixed effects

\begin{tabular}{lccrr}
\hline Source & $\begin{array}{c}\text { Numerator } \\
\mathrm{df}\end{array}$ & $\begin{array}{c}\text { Denominator } \\
\mathrm{df}\end{array}$ & $\mathrm{F}$ & \multicolumn{1}{c}{ Sig. } \\
\hline Intercept & 1 & 646.531 & 599.120 & .000 \\
GDP & 9 & 138.398 & 1.386 & 0.200 \\
\hline Note. NOP = Dependent variable & & &
\end{tabular}

The results shown in Table 6 indicated that annual GDP growth had no significant effect on the regression model. This indicated that the relationship between WCM and profitability remained significant in different economic conditions and GDP had no significant effect on the examined relationship.

\section{Discussion}

The results presented have shown the relationship between WCM and various profitability proxies (ROA, ROE, ROCE, GOP, and NOP). The results have shown more than one statistically significant relationship between the profitability proxies and the independent variables. Therefore, H1, H2, H4, and H5 were accepted. However, H3, $\mathrm{H} 6$, and $\mathrm{H} 7$ were rejected.

The results of this study showed a statistically significant negative relationship between RCP and profitability. This result matches with a number of previous studies, such as Deloof (2003), Enqvist et al. (2014), Ukaegbu (2014), and Pais and Gama (2015). This means that managers may increase the company profitability by decreasing the number of days of the RCP.

The APP is the number of days that a company waits to pay its suppliers. The results of this study showed a statistically significant negative relationship between APP and profitability. This result concurs with a number of previous studies, such as Deloof (2003), Enqvist et al. (2014), Afrifa (2015), and Samiloglu and Akgun (2016). According to the results of this study, a company could increase its profitability by accelerating its payments to suppliers, as companies that paid sooner could take advantage of discount opportunities from suppliers. 
The results show a positive (though not statistically significant) relationship between inventory turnover and profitability which agrees with a number of previous studies, such as Enqvist et al. (2014), Ukaegbu (2014), Afrifa (2015), and Samiloglu and Akgun (2016) who argued that increasing inventory turnover reduces holding costs such as rent of warehouse, insurance, and unnecessarily tying funds to inventory, which could lead to increase profitability. Conversely, Deloof (2003) argued that high inventory could lead to higher sales and reduce the risk of a stock-out, which could increase profitability. The results showed a weak relationship between INP and profitability, support both theories, indicating that it is not a linear relationship; however, the best WCM decision would be obtaining the right amount of inventory to reduce holding costs but not cause a shortage in the inventory.

The results indicate that $\mathrm{CR}$ is the most important variable that predicts profitability, which agrees with the results of previous studies in Saudi Arabia (Eljelly, 2004; Almazari, 2013). However, those studies found a negative relationship between CR and profitability, whereas our results showed a positive relationship between CR and profitability. While many changes have occurred since the time of those earlier studies, the results of this study could be an important indicator that the relationship between WCM and profitability is not linear.

The results showed a statistically positive relationship between WCM, measured by CR, RCP, APP, INP, and profitability; however, this was a weak linear relationship. A number of previous studies have tried to tie good WCM to specific practices, such as increasing or decreasing CR, RCP, APP, and INP. However, comparing our results with those of previous studies, we argue that good WCM takes place when a manager develops the most suitable strategy for the company, whether it is decreasing or increasing working capital components.

This study found a statistically significant positive relationship between company size and profitability, using ROE as a proxy. This positive relationship agrees with previous studies, such as Ukaegbu (2014), Pais and Gama (2015), Lyngstadaas and Berg (2016), and Samiloglu and Akgun (2016). However, we could not find a significant relationship between Size and the other profitability proxies.

Previous studies have argued that the condition of the economy affects the relationship between WCM and profitability especially in recession (Enqvist et al., 2014; Singhania et al., 2014; Ukaegbu, 2014). However, we could not find a significant effect of GDP, as an economy condition proxy, on the relationship between WCM and profitability. One explanation of this could be that economic condition does not affect this relationship and it remains significant in all economic states. Future studies can test this relationship in a different period or in a different market in which there is more obvious economic fluctuations.

To conclude, the results show a statistically significant positive relationship between WCM and profitability. However, it was a weak linear relationship. It indicated that no single constant practice or WCM strategy would suit every company. The results showed a significant relationship between company size and working capital management, which could be a sign that such corporate characteristics could affect the optimal level of working capital, which affects profitability. Finally, this study could not find a significant effect of GDP on the tested relationship which support the argument that WCM remains significant regardless of the economic condition.

The major limitation of this study is its generalizability. It is limited to non-financial companies listed on the Saudi Arabia Stock Exchange. The results indicate a weak linear relationship between WCM and profitability, indicating that no single constant practice or strategy would suit every company, managers should identify the optimal level of working capital that suits their company's situation. Previous studies in other countries have shown different relationships between WCM and profitability, which could indicate that there are other variables affecting this relationship, and therefore, the results of this study cannot be generalized to other countries.

\section{Acknowledgements}

This study was supported by the Institute of Public Administration in Saudi Arabia and the Saudi Culture Mission in Australia. Also, I would like to express my very great appreciation to Ms. Sadia Qumber for her help in editing the manuscript.

\section{References}

Ali, A., \& Ali, S. A. (2012). Working capital management: Is it really affects the profitability? Evidence from Pakistan. Global Journal of Management and Business Research, 12(17).

Afrifa, G. A. (2015). Working capital management practices and profitability of AIM listed SMEs. Journal of Enterprising Culture, 23(01), 1-23. https://doi.org/10.1142/S0218495815500016

Ahmed, Z., Awan, M. Z., Safdar, M. Z., Hasnain, T., \& Kamran, M. (2016). A nexus between working capital management and profitability: A case study of pharmaceutical sector in Pakistan. International Journal of Economics and Financial Issues, 6(3S), 153-160. 
Almazari, A. A. (2013). The relationship between working capital management and profitability: evidence fromSaudi cement companies. British Journal of Economics, Management \& Trade, 4(1), 146-157. https://doi.org/10.9734/BJEMT/2014/5427

Allen, P., \& Bennett, K. (2012). SPSS Statistics-A Practical Guide. Cengage Learning: Australia Pty Ltd.

Arshad, Z., \& Gondal, M. Y. (2013). Impact of working capital management on profitability a case of the Pakistan cement industry. Interdisciplinary Journal of Contemporary Research in Business, 5(2), 384-390.

Baños-Caballero, S., García-Teruel, P. J., \& Martínez-Solano, P. (2014). Working capital management, corporate performance, and financial constraints. Journal of Business Research, 67(3), 332-338. https://doi.org/10.1016/j.jbusres.2013.01.016

Barber, B. M., \& Lyon, J. D. (1996). Detecting abnormal operating performance: The empirical power and specification of test statistics. Journal of Financial Economics, 41(3), 359-399. https://doi.org/10.1016/0304-405X(96)84701-5

Danuletiu, A. E. (2010). Working Capital Management and Profitability: A Case of Alba County Companies. Annales Universitatis Apulensis-Series Oeconomica, 12(1).

Deloof, M. (2003). Does working capital management affect profitability of Belgian firms? Journal of Business Finance \& Accounting, 30(3-4), 573-588. https://doi.org/10.1111/1468-5957.00008

Eljelly, A. M. (2004). Liquidity-profitability tradeoff: An empirical investigation in an emerging market. International Journal of Commerce and Management, 14(2), 48-61. https://doi.org/10.1108/10569210480000179

Enqvist, J., Graham, M., \& Nikkinen, J. (2014). The impact of working capital management on firm profitability in different business cycles: Evidence from Finland. Research in International Business and Finance, 32, 36-49. https://doi.org/10.1016/j.ribaf.2014.03.005

Ghaziani, S. M. T., Biabani, S., \& Zadeh, R. B. H. (2012). Investigation of the relationship between component of working capital management with market valuation and profitability in firms listed in Tehran Stock Exchange. Trends in Social Science, 5(1), 54-63.

Haron, R., \& Nomran, N. M. (2016). Determinants of working capital management before, during, and after the global financial crisis of 2008: Evidence from Malaysia. The Journal of Developing Areas, 50(5), 461-468. https://doi.org/10.1353/jda.2016.0029

Hillier, D. R. S., Westerfield, R., Jaffe, J., \& Jordan, B. (2010). Corporate Finance. Berkshire: McGraw-Hill.

Jose, M. L., Lancaster, C., \& Stevens, J. L. (1996). Corporate returns and cash conversion cycles. Journal of Economics and Finance, 20(1), 33. https://doi.org/10.1007/BF02920497

Korajczyk, R. A., \& Levy, A. (2003). Capital structure choice: macroeconomic conditions and financial constraints. Journal of Financial Economics, 68(1), 75-109. https://doi.org/10.1016/S0304-405X(02)00249-0

Kimmel, P. D., Weygandt, J. J, \& Kieso, D. E. (2010). Financial accounting: tools for business decision making. John Wiley \& Sons: New York.

Lyngstadaas, H., \& Berg, T. (2016). Working capital management: evidence from Norway. International Journal of Managerial Finance, 12(3), 295-313. https://doi.org/10.1108/IJMF-01-2016-0012

Madhou, A., Moosa, I., \& Ramiah, V. (2015). Working capital as a determinant of corporate profitability. Review of Pacific Basin Financial Markets and Policies, 18(04), 1550024. https://doi.org/10.1142/S0219091515500241

Mohamad, N. E. A. B., \& Saad, N. B. M. (2010). Working capital management: The effect of market valuation and profitability in Malaysia. International Journal of Business and Management, 5(11), 140. https://doi.org/10.5539/ijbm.v5n11p140

Mun, S. G., \& Jang, S. S. (2015). Working capital, cash holding, and profitability of restaurant firms. International Journal of Hospitality Management, 4, 1-11. https://doi.org/10.1016/j.ijhm.2015.04.003

Muhammad, H., Rehman, A. U., \& Waqas, M. (2016). The relationship between working capital management and profitability: A case study of tobacco industry of Pakistan. The Journal of Asian Finance, Economics and Business, 3(2), 13-20. https://doi.org/10.13106/jafeb.2016.vol3.no2.13.

Nurunnabi, M. (2017). IFRS and Saudi accounting standards: A critical investigation. International Journal of 
Disclosure and Governance, 14(3), 191-206. https://doi.org/10.1057/s41310-017-0020-0

Naser, K., Nuseibeh, R., \& Al-Hadeya, A. (2013). Factors influencing corporate working capital management: Evidence from an emerging economy. Journal of Contemporary Issues in Business Research, 2(1), 11-30.

Pass, C. L., \& Pike, R. H. (1984). An overview of working capital management and corporate financing. Managerial Finance, 10(3), 1-11. https://doi.org/10.1108/eb027318

Petersen, M. A., \& Rajan, R. G. (1997). Trade credit: theories and evidence. The Review of Financial Studies, 10(3), 661-691. https://doi.org/10.1093/rfs/10.3.661

Pais, M. A., \& Gama, P. M. (2015). Working capital management and SMEs profitability: Portuguese evidence. International Journal of Managerial Finance, 11(3), 341-358. https://doi.org/10.1108/IJMF-11-2014-0170

Raheman, A., \& Nasr, M. (2007). Working capital management and profitability-case of Pakistani firms. International review of business research papers, 3(1), 279-300.

Raheman, A., Afza, T., Qayyum, A., \& Bodla, M. A. (2010). Working capital management and corporate performance of manufacturing sector in Pakistan. International Research Journal of Finance and Economics, 47(1), 156-169.

Rahman, M. M. (2011). Working capital management and profitability: a study on textiles industry. ASA University Review, 5(1), 115-132.

Samiloglu, F., \& Akgün, A. İ. (2016). The relationship between working capital management and profitability: Evidence from Turkey. Business and Economics Research Journal, 7(2), 1. https://doi.org/10.20409/berj.2016217492

Sagner, J. (2014). Working Capital Management: Applications and Case Studies. John Wiley \& Sons: New York.

Singhania, M., Sharma, N., \& Rohit, J. Y. (2014). Working capital management and profitability: evidence from Indian manufacturing companies. Decision, 41(3), 313-326. https://doi.org/10.1007/s40622-014-0043-3

Singh, J. P., \& Pandey, S. (2008). Impact of Working Capital Management in the Profitability of Hindalco Industries Limited. ICFAI journal of financial Economics 6(4).

Singh, H. P., Kumar, S., \& Colombage, S. (2017). Working capital management and firm profitability: a meta-analysis. Qualitative Research in Financial Markets, 9(1), 34-47. https://doi.org/10.1108/QRFM-06-2016- 0018

Smith, K. (1980). Profitability versus Liquidity Tradeoffs in Working Capital Management, in Readings on the Management of Working Capital. West Publishing Company: New York.

Shin, H. H., \& Soenen, L. (1998). Efficiency of working capital management and corporate profitability. Financial Practice and Education, 8, 37-45.

Soenen, L. A. (1993). Cash conversion cycle and corporate profitability. Journal of Cash Management, 13, 53-53.

Usama, M. (2012). Working Capital Management and its effect on firm's profitability and liquidity: In Other food sector of (KSE) Karachi Stock Exchange. Oman Chapter of Arabian Journal of Business and Management Review, 34(969), 1-12. https://doi.org/10.12816/0002232

Uyar, A. (2009). The relationship of cash conversion cycle with firm size and profitability: an empirical investigation in Turkey. International Research Journal of Finance and Economics, 24(2), 186-193.

Ukaegbu, B. (2014). The significance of working capital management in determining firm profitability: Evidence from developing economies in Africa. Research in International Business and Finance, 31, 1-16. https://doi.org/10.1016/j.ribaf.2013.11.005

Wang, Y. J. (2002). Liquidity management, operating performance, and corporate value: evidence from Japan and Taiwan. Journal of Multinational Financial Management, 12(2), 159-169. https://doi.org/10.1016/S1042- 444X(01)00047-0

\section{Copyrights}

Copyright for this article is retained by the author(s), with first publication rights granted to the journal.

This is an open-access article distributed under the terms and conditions of the Creative Commons Attribution license (http://creativecommons.org/licenses/by/4.0/). 